\title{
東京低地の液状化予測 \\ LIQUEFACTION POTENTIAL MAP IN TOKYO LOWLAND
}

\author{
草野郁*.阿部博**.小川好***. 中山俊雄**** \\ By Kaoru KUSANO, Hiroshi ABE, Yoshimi OGAWA and Toshio NAKAYAMA
}

\begin{abstract}
In order to identify liquefaction susceptibility for wide area, it is necessary to have as much information as possible in the area under consideration. In this study, a computer aided system has been developed to facilitate engineering decision-making concerning liquefaction susceptibility. The man-machine interactive system and graphic display capability give an engineer not only the final evaluated result but also information needed to understand the background knowledge on the factors of liquefaction likelihood. The liquefaction potential lots map in Tokyo Lowland was compiled from the indices of liquefaction potential analysis, the information about liquefaction generated during the Kanto earthquake, and the characteristics of geography and geology.

The system engineering procedure was useful for the interactive evaluation of a great amount of information and for the decision about poorly defined problems such as the assessment of liquefaction potential mapping. A result of these studies showed that the liquefiable area was about one forth of Tokyo Lowland.
\end{abstract}

Keywords : liquefaction, liquefaction potential index, geography, geology, lots map

\section{1.はじめに}

東京低地は表層に軟弱な砂質土が広く分布しており， 関東地震においても液状化が発生した1)。このため, 大 地震の際には液状化による大きな災害が予想され，液状 化の危険地域を予測し適切な対策を立てる必要があり， 東京都は地震被害想定の一環として先に“東京低地の液 状化予測”1を発表した。この研究はそこで検討された 液状化予測手法と予測結果をまとめたものである.

広域を対象とする地盤の液状化予測では，構造物の耐 震性の検討のように対象が特定された予測とは異なり， 液状化によって引き起こされるさまざまな災害を配慮す る必要がある.さらに, 地盤が地域的に変化に富み複雑 であるにもかかわらず，収集される土質調査資料は限定 される.このため, ボーリング資料の液状化解析あるい は地形分類など個々に情報を取り上げても広域的な予測 には結び付きにくい場合が多く，限られた情報をどのよ うに予測に結び付け利用するかが問題となる．とくに東 京低地は昔からの埋土や盛土, さらには都市化による人

* 正会員 工修 東京都土木技術研究所 （T108 港区港南 1-1-18）

** 正会員 工修 東京都土木技術研究所 (同上)

*** 正会員 東京都土木技術研究所 (同上)

**** 東京都土木技術研究所 (同上)
工改変が著しく，また，表層に分布する砂層は細粒分を 多く含む.このため, 東京低地の液状化予測では地域特 性に適した情報の把握と予測法の検討が不可欠になる. この研究では，多数の情報から予測に影響を及ぼす要因 を抽出し, 総合化することにより東京低地の液状化予測 を行った.

予測は, 関東地震規模の地震動の襲来を想定し都内 14 区を対象とした。湾岸部の最近埋立てた地域は東京 都港湾局が調查中であったことから対象地域から除外し た。

\section{2. 広域を対象とする液状化予測の考え方}

\section{（1）基本的な考元方}

地盤の液状化予測を行うにあたり利用できる情報は, 次の 3 種類に区分することができる（図一1).

(1) 過去の地震における対象地域内の液状化発生・非 発生の調查結果（液状化履歴）

(2) 地形分類図などから得られる地形の情報と地盤図 などから得られる地質の情報

(3) ボーリング地点での液状化解析から得られる情報

(1)の情報は，(2)および(3)の情報を利用し広域的な液状 化予測を行ううえでの判断規準を与えるものであり，そ の地域の液状化特性を把握するには確実な情報である 


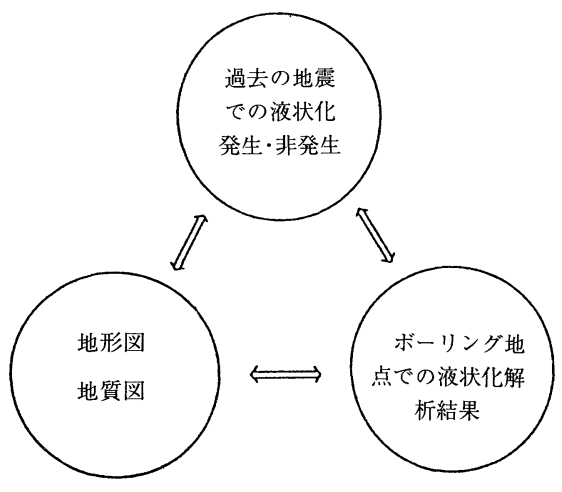

図一1＼cjkstart地盤の液状化特性の把握

が，地盤が改変されていたり，地震規模が異なる場合， 過去に液状化したところでも再び液状化するとは限らな い. また, 予測対象地域全域を調査し網羅することはで きない.

(2)の情報は対象地域全域を覆うことができるが, 地 形・地質の名称分類は地盤の液状化特性を表すことを目 的としたものではないため, 対象とする地域の地盤の液 状化特性に関連させて検討されない限りその地域の液状 化の可能性について概略的な情報を与えるに過ぎない.

(3)の情報は現状の地盤の液状化特性を定量的に表わす ことができるが, 地点としての情報を与えるに過ぎない. 広域的な液状化予測を行う場合, 膨大な数のボーリング 資料を収集するが, 対象地域全域を網羅することは不可 能である.また, 収集されたボーリング資料は液状化調 查を目的としたものでないため液状化解析に必要な砂層 の粒度試験などの情報を欠くものが多い.

広域を対象とした液状化予測では，ボーリング資料が 不足しているなど情報が欠けている地域についても, 図 一1に示すように情報相互の関係から不足している情報 を他の情報によって補い, 対象地域全域を統一のとれた 評価規準に基づいて判定する必要がある.ここでは, 図 -1 に示す 3 つの情報間の関係から東京低地の地盤特性 に適した予測法と地形・地質情報の利用法を検討した.

\section{（2）液状化履歴と予測式}

関東震災体験者を対象とした面接調查加, 関東地震 における東京低地の液状化履歴図を領域図として作成し $た^{2)}$. 液状化発生・非発生地域の土質特性を調べると, 細粒分をあまり含まない砂層は液状化が発生しやすく, 細粒分を多く含む砂層は液状化が発生しにくい結果が得 られた ${ }^{21}$. 東京低地で採取した不視乱試料の繰り返し三 軸試験によると, 細粒分を多く含む砂質土は標準貫入試 験の $N$ 值が小さく軟弱であるにもかかわらず液状化強 度は大きくなり, 液状化履歴調查の結果と符合する傾向 がみられた。このような液状化特性を表わす式として,
$N$ 值と有効上載圧から求まる強度応力比に平均粒径に よる補正項だけでなく, 細粒分含有率, 拘束応力による 補正項も加えた液状化強度推定式を作成した ${ }^{3)}$.

地震時荷重は, 東京低地の地震応答解析結果から得ら れた軟弱層厚と応答倍率の関係を使用し, 東京低地全域 の平均的な地表面最大加速度が $0.25 \mathrm{~g}$ の值を示す基盤 入力最大加速度 $170 \mathrm{gal}$ の解析結果から推定した³). 今 回の予測では関東地震規模を想定していることから,こ の地震規模に近い十勝沖地震 (1968 年 5 月) の際に運 輸省が青森県八戸港で観測した加速度波形 (八戸 N-S を基盤の入射波形に変換 $\left.{ }^{4}\right)$ を基盤入力波形として使用 した.

\section{（3）予測作業の概要}

予測作業のフローを図一2に示す.

地形の情報としては，土地条件図 ${ }^{5)}$, 旧版地形図から 土地分類図, 水系図, 湿地水田分布図を作成し ${ }^{11}$, 地質 の情報としては，ボーリング柱状図から砂層，磁層，表 層分布図, 地下水面図を作成した ${ }^{1}$. 関東地震液状化履 歴図, 家屋被害分布図 ${ }^{6)}$ を含め, すべての地図類を地図 情報として数值ファイル化した。

ボーリング地点の液状化解析では, 約 12000 本のボー リング資料を柱状図情報として数值ファイル化し, 提案 した液状化予測式を使用し液状化計算を行った。

関東地震液状化履歴図之地形・地質図の数值化された 情報を重和合わせ，地形・地質図の各凡例に区分される 地域内の液状化発生と非発生の面積比加, 液状化しゃ すい地形・地質の分類を求めた。関東地震液状化履歴図 之液状化発生・非発生地域に含まれるボーリング地点の 液状化解析結果を集計し, 液状化の程度と解析值の関係 を求めた。地形・地質図とボーリング地点の液状化解析 結果の比較から，地形・地質図のおのおのの分類が液状 化の可能性によ゙の程度関連するかを調べた.

このような検討から図一1に示す情報間の関連を整理 し, ボーリング地点の液状化解析值と液状化履歴, 地形 · 地質の地図情報を重称合わせて液状化判定を行った。

地域を一定の大きさ (500 mメッシュ)に分割し，メッ シュ内の諸情報を重ね合わせ液状化の可能性を総合的に 評価するメッシュ判定法により液状化予測図を作成し た.

\section{3. 液状化予測支援システムと解析結果}

\section{(1) 支援システム}

地図および柱状図の大量な情報を処理し液状化解析を 行うことを目的として情報処理システムを作成した。こ れを液状化予測支援システムと称す。このシステムには, 多数の情報を処理し液状化計算を行う情報処理機能のほ かに，図一 1 に示す 3 種類の異なる情報の相互関係を検 
渦去の地震での液状化 履歴の情報

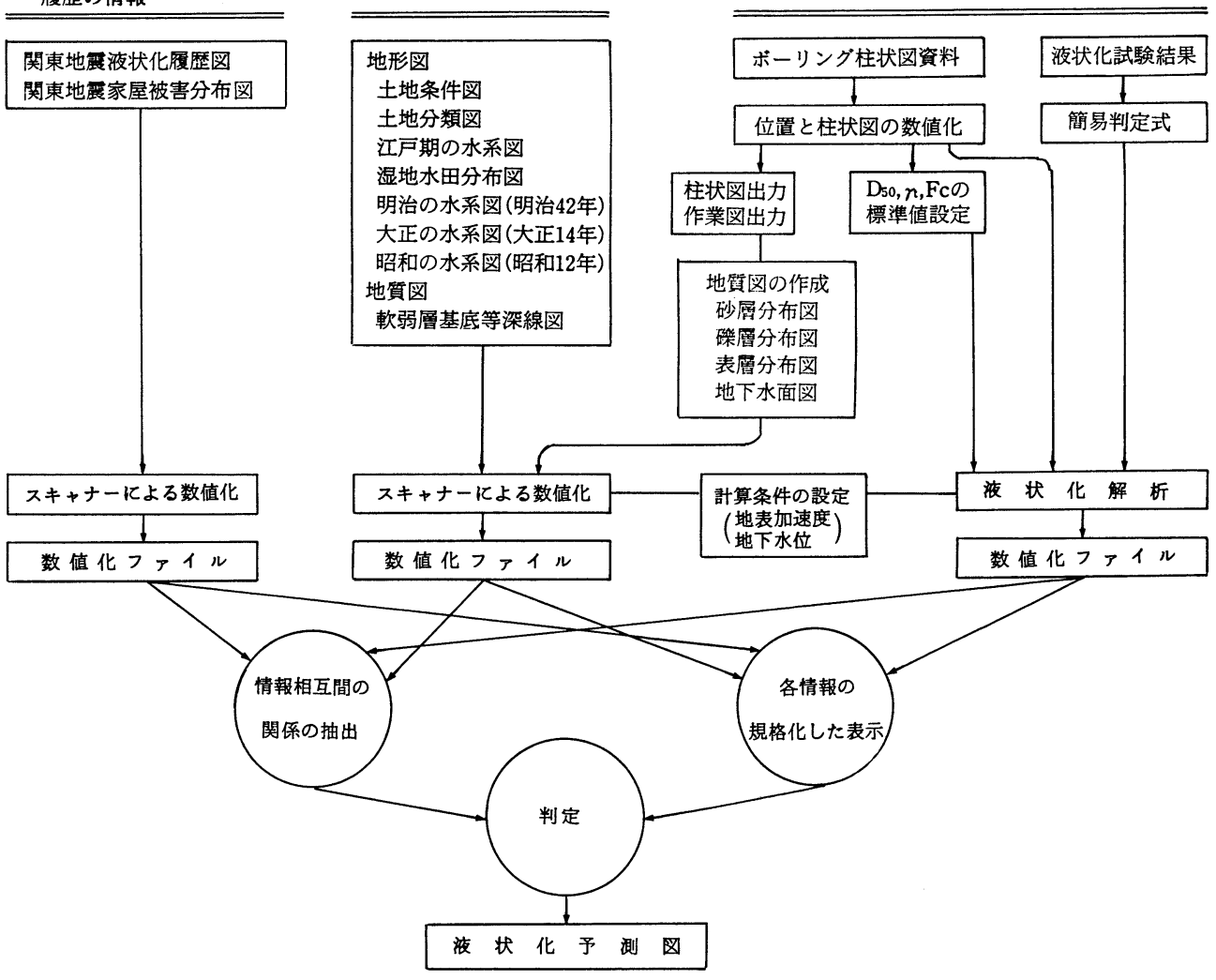

地形・地質の情報

図一2 液状化予測のフロー
索する機能と，情報を一定の規格のもとに視覚化し，対 話形式で液状化判定を行うことができる機能をもたせ た.さらに，液状化予測という目的に至る過程を分析し 構造化するというシステム工学的な面も配慮した。

液状化解析や情報間の相互関係の検索のような大量の 情報処理を短時間で行う場合は汎用型計算機を使用した が，その他はパソコンによる表示機能を中核とし，予測 に向けた試行錯誤を伴う作業を行いやすくした.

a）地図情報，柱状図情報の数值ファイル化亡液状化 解析

地図情報は，地図の凡例にコードを付加して分類の認 識ができる入力方法により数值化し，地図の凡例による 検索，統計処理が行えるシステムとした。 入力した地図 情報は国土地理院標準地域メッシュ第 3 地域区画の 4 つ のメッシュ（約 $2 \mathrm{~km} \times 2 \mathrm{~km}$ ) をパソコン上で 1 画像と して出力し, さらにこれを 16 分割してメッシュ判定の 単元である $500 \mathrm{~m}$ メッシュに区分し，単元ごとに凡例 の占める面積を表示し対話形式で液状化判定ができるよ うにした。

入力した地図情報の概要を次に示す.

関東地震の災害に関連する図面としては,
- 関東地震液状化履歴図 ${ }^{2)}$ : 激しい液状化の発生地域 （砂や水の激しい噴出，地盤の陥没，地盤の強度低下に よる構造物の大きな被害), 軽度な液状化の発生地域 (砂 や水のわずかな噴出, 井戸の被害, 地盤の沈下, 地盤の 強度低下による構造物の比較的軽度な被害), 井戸水の 変化・地割れした地域（井戸水の濁りや水位上昇, 地割 れ，堤防などの破壊に至らない亀裂）と地盤災害がない 地域を領域で表わした。

- 関東地震家屋被害分布図 ${ }^{6)}$ : 地質調查所で行った木造 家屋被害の調査結果で, 家屋被害大・やや大・顕著でな い，土地の陥没を $1 / 25000$ の地図上に表わした.

地形の情報としては,

- 土地条件図 ${ }^{5)}$ : 人工地形のうち旧水面上の盛土地と旧 水面上の高い盛土地が区別されている 1970 年版を用い た。

-土地分類図：人工改変が加えられる以前の微地形をみ る目的で土地条件図, 洪水地形分類図 ${ }^{7}$ をもとに作成し た. 分類は台地, 台地斜面, 谷底地, 氾濫平野, 三角州 の 5 分類とし, 自然堤防や旧河道, 旧水面上の盛土といっ た土地条件図ですでに明示されていて人工改変をあまり 受けていないものや改変が明らかな微地形は除いた。 

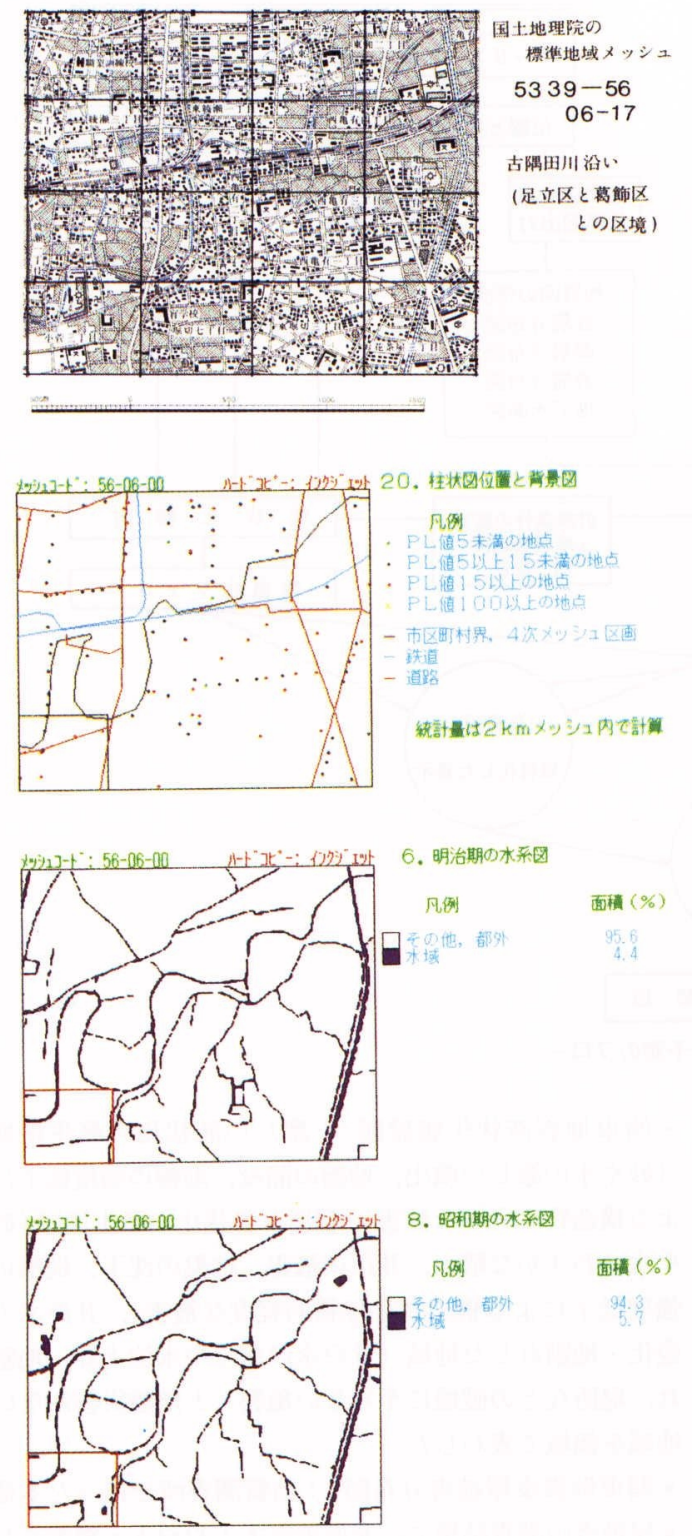

面腈 (\%)

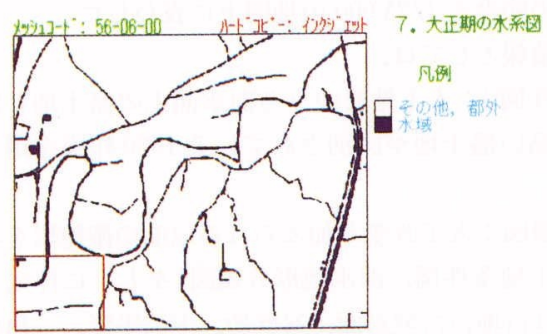

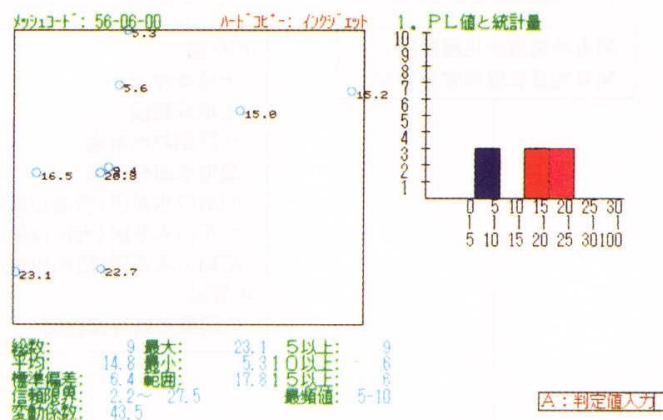
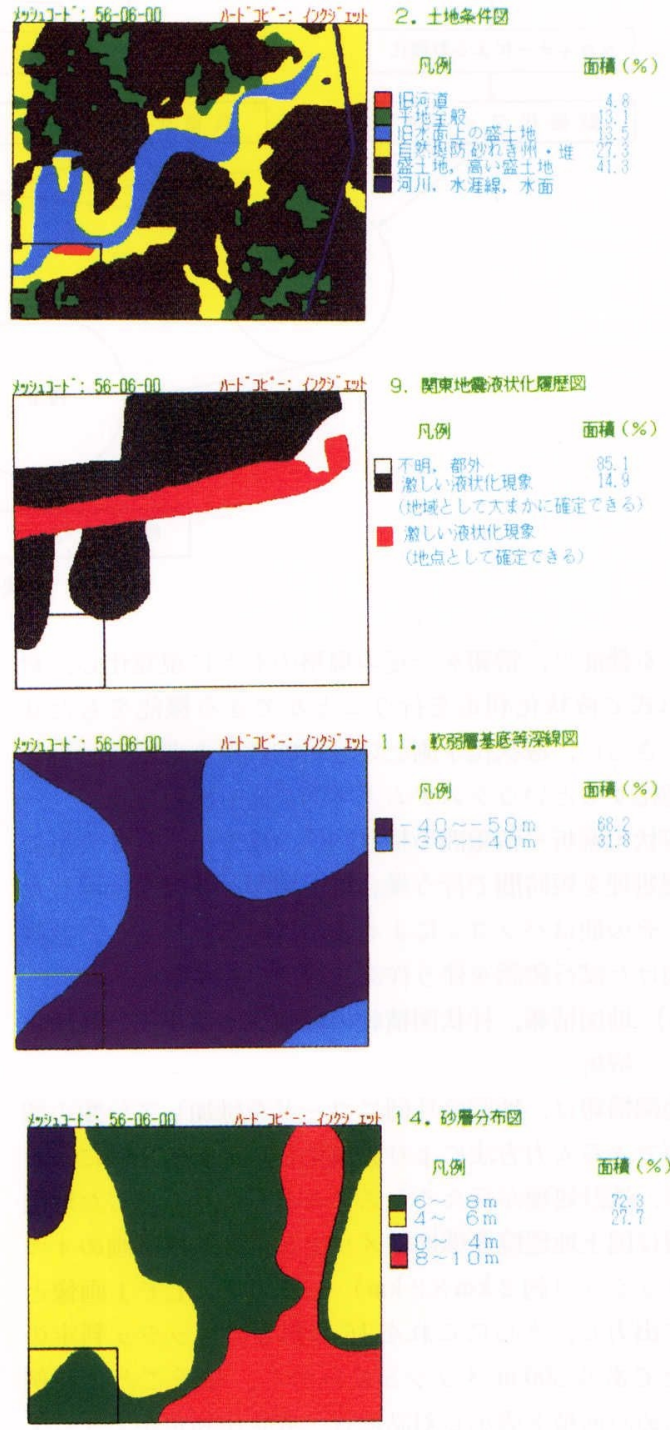

面穔 $(\%)$

図一3 地図情報とボーリング地点での液状化解析値の出力例 
- 湿地水田分布図：土地利用のうち水に関連するもので あり，最も古い情報を得る目的から，明治 $13 \sim 17$ 年測 図の迅速図 ${ }^{8)}$ から湿地, 水田, 田を読み取り入力した.

- 江戸期の水系図 : “江戸期の地形と水系と海岸線の変 化” ${ }^{9)}$ を 1/25000 の地図上に, 1460 年頃の水系と湿地 · 陸地，1632 年まで・1670 年まで・1860 年までに陸化し た地域，隅田川および東京湾の 7 分類で表わした.

- 旧版地形図の水系図：明治 42 年亡大正 14 年, 昭和 12 年に测図された旧版地形図から水系に関連する項目 を選び出し, 水系, 海, 湿地, 砂州, その他に分類し入 力した.

地質の情報としては,

・軟弱層基底等深線図 ${ }^{10)}$ : 有楽町層または七号地層の基 底面の深度を表わし, 軟弱層の層厚を示す。この図は地 表面最大加速度の推定に使用する目的で入力した.

-入力地下水面図：地表近くの自由地下水位を区分し表 わした．液状化解析結果は地下水位により影響を受けや すいことから，地下水面図の季節変動を考慮し安全を見 込んで高い時期の水位を想定して作成した.

-砂層分布図：有楽町層上部は砂層を主体とした沖積層 であるため，この層厚図を砂層分布図として入力した。

- 砅層分布図: 沖積層の碩層のうち, 出現深度が $5 \mathrm{~m}$ 末満の地域を図示した。

-表層分布図：表土や盛土が砂質土であるか粘性土や瓦 碩であるかによって液状化に及ぼす影響は異なる。ボー リング柱状図で表土や盛土と表示されており，記事欄か ら砂質土と判断できるものを選び，ボーリング地点を中 心とする半径の $100 \mathrm{~m}$ の円で表わした.

このほかにボーリング深度図, 柱状図位置図と国土数 值情報 ${ }^{11)}$ による背景図がある11. パソコンの画像で表示 した出力図の例を図一 3 に示す.

柱状図情報としては, 約 12000 本のボーリング資料 の土質柱状図，土質試験結果を数值ファイル化したうえ で, 液状化解析に必要な土質パラメーターの集計, 液状 化予測に必要な地質図作成のための出力, および, 地図 情報（入力地下水面図と軟弱層基底等深線図）と柱状図 情報とから液状化計算が行えるシステムを作成した ${ }^{11}$.

ボーリング資料に記載されている土質名称をコード化 し, 各コードに分類される粒度と密度の試験データを集 計し, 土質名称ごとに液状化解析に必要な土質パラメ一 ターの標準値 ${ }^{1}$ をえた.

液状化解析では，土質試験データのあるものはそれを 使用し, ないものは土質パラメーターの標準値を使用し た.また，ボーリングデータの水位が入力地下水面図よ り低い場合は安全側を見込んで入力地下水面図の水位を 使用して解析モデルを設定した．軟弱層厚と地震応答倍 率の関係から軟弱層基底等深線図を使用し地表最大加速
度を推定し液状化解析を行い, 液状化抵抗係数 $F_{L}$ 值と 液状化指数 $P_{L}$ 值を求めた. 解析結果をボーリング地点 の位置情報として数值ファイル化し，500 mメッシュご とに集計し $P_{L}$ 值の頻度分布を求められるようにした.

b）情報相互間の関連抽出法

図一1に示す情報相互間の関係を求めることを目的と して，地図情報間では地図の凡例間 “面と面” の関係抽 出, ボーリング地点の解析值と地図情報との間では解析 值と地図の凡例間 “点と面” の関係抽出が可能なシステ ムを作成した。

地図の形で表現される “面と面” の情報間の関係を求 める場合，たとえば，土地条件図での三角州や旧河道等 の凡例で区分される地域が関東地震でごの程度液状化し たかを調べるには，土地条件図と関東地震液状化履歴図 を重水合わせ, 三角州や旧河道の地域内における液状化 発生と非発生の面積を集計することにより評価すること ができる．この種の重ね合わせの方法は図一4に示すよ うに，数值化された地図情報の重ね合わせにより，各凡 例の組合せによって生成される領域を新たな凡例として 区分しその面積集計を行うことである.

ボーリング地点の解析值である “点” の情報と地図情 報である“面”の情報との関係を求める場合には, 地図 の凡例で括られる領域中に含まれるボーリング地点の情 報 $\left(P_{L}\right.$ 値) を集計し, 頻度分布により評価する. 地図

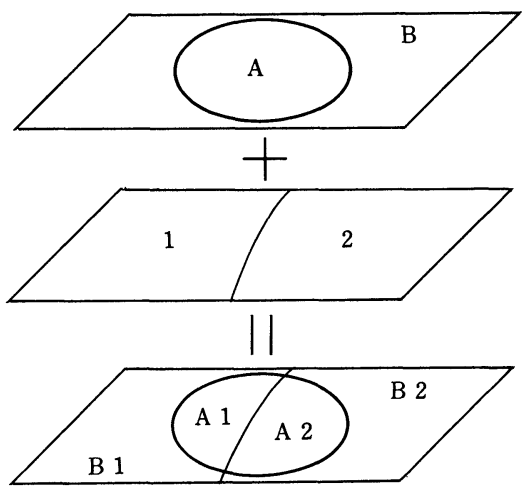

図一4 領域の重ね合わせの概念

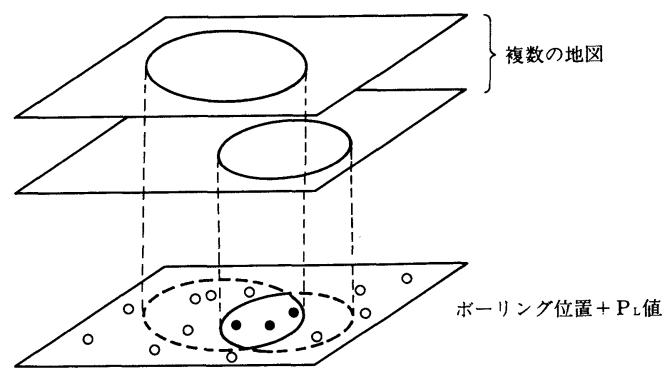

図一5領域と地点の重ね合わせの概念 


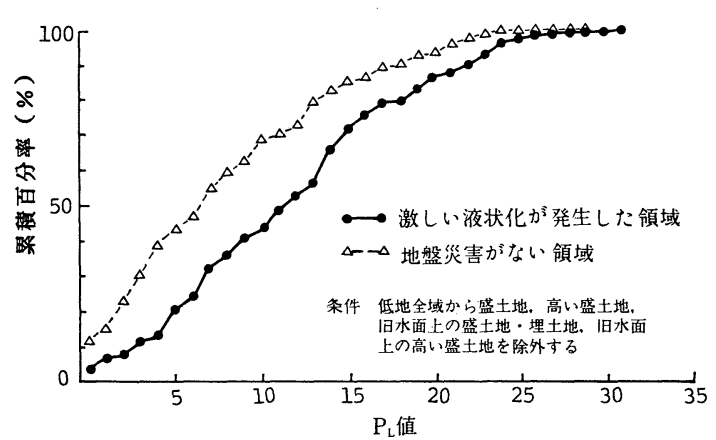

図一 6 液状化発生 - 非発生地域の $P_{L}$ 值の累積頻度曲線

各地形区分に含まれる/ 調查地域内の各地形 液状化発生地域の面積 区分の占める面積 (\%) 土地条件図

三角州
氾濫平野
自然堤防
頻水地形
上の盛土地
干拓地

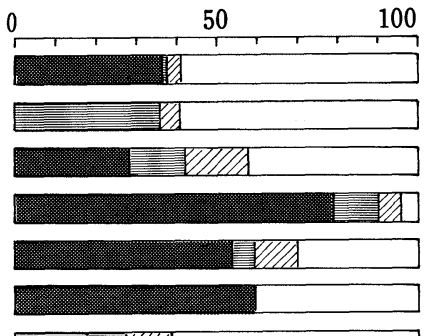

砂(砅)州・砂(磎)堆 台地(段丘と平坦化地, 台地斜面を含む)

\begin{tabular}{|c|c|c|}
\hline 凡例 & & 地盤災害なし \\
\hline U罗 & & $\begin{array}{l}\text { 軽度の液状化 } \\
\text { 激しい液状化 }\end{array}$ \\
\hline
\end{tabular}

\section{図一7液状化履歴と土地条件図の関係}

情報の選定は，図一5 に示すように，1 種類の地図の情 報だけでなく, 数種類の地図の凡例の組合せもできるよ うにした。 たとえば土地条件図において, 関東地震以降 地盤改変が進められたと判断できる旧水面上の盛土地・ 埋土地・高い盛土地などの凡例を除いた地域で, 関東地 震液状化履歴図で液状化した地域に含まれる $P_{L}$ 值を集 計することが可能である. 集計の組合せは多数に及び試 行錯誤の選択が予想されたことから, パソコンを使用し 対話形式で集計がとれるようにした。

\section{（2）支援システムによる解析結果}

関東地震液状化履歴と $P_{L}$ 值の関係としては, 履歴図 の凡例で激しい液状化現象が生じた（液状化発生）地域 と液状化も地割れもない地盤災害がない（非液状化）地 域の $P_{L}$ 值の累積頻度曲線を求め図一6に示す. 関東地 震液状化履歴と地形・地質の関係を求めた事例として, 土地条件図との関係を図一7に, 砂層分布図との関係を 図一8に示す. 解析值と地形・地質の関係を求めた事例 として $P_{L}$ 値と土地条件図の関係を図一 9 に示す.

図一6では, 液状化の可能性と $P_{L}$ 值の関係を求める
各砂層区分に含まれる/調查地域内の各砂層 液状化発生地域の面積 区分の占める面積 砂層厚

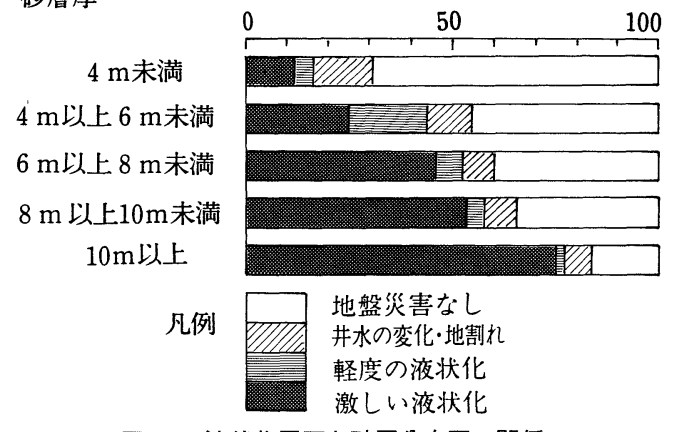

図一8 液状化履歴と砂層分布図の関係

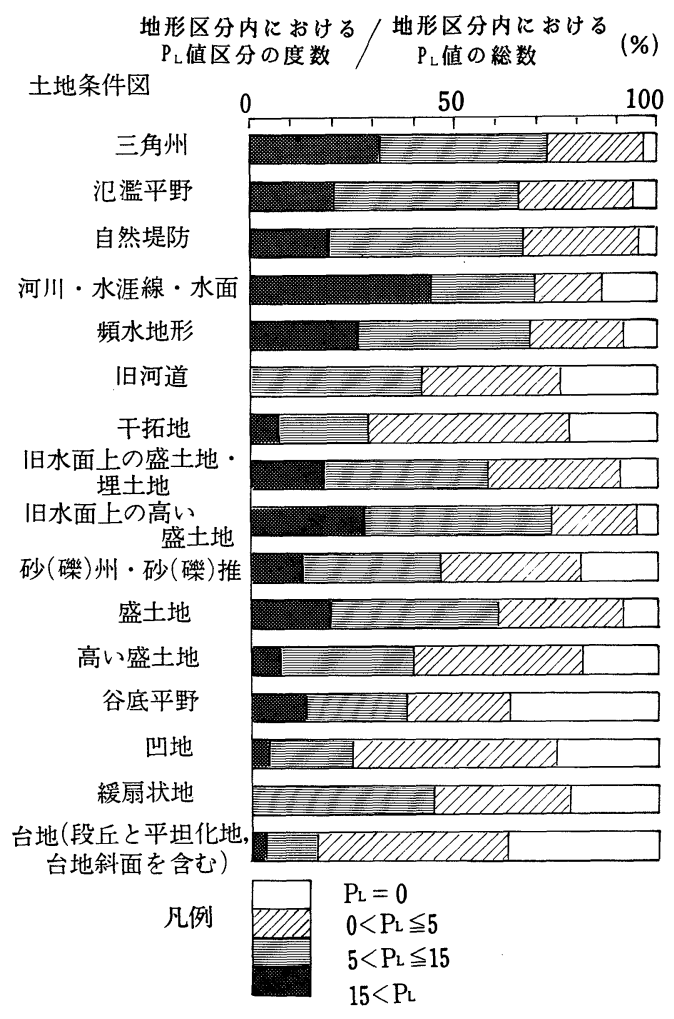

図一9 土地条件図と $P_{L}$ 值の関係

ことを目的としているため, 震災当時と地盤の液状化特 性に大きな差がない地域の $P_{L}$ 值を選択する必要があ る.このため, 震災以降に地盤の改変が進んだと考えら れる盛土地, 高い盛土地, 旧水面上の盛土地 - 埋土地, 旧水面上の高い盛土地に含まれる $P_{L}$ 值を除外した. 図 一6によると, 関東地震で激しい液状化が発生した地域 の $P_{L}$ 值は無被害の地域の $P_{L}$ 值より大きくなり, $P_{L}$ 值 により液状化の可能性を区分できることがわかる.

図一7によると, 液状化しやすい地形の分類は頻水地 
形, 干拓地, 旧水面上の盛土地・埋土地であり, 液状化 しにくい地形の分類は低地では砂（碩）州, 砂 (碩) 堆 である，図一8によると，砂層を主体とする有楽町層上 部の層厚が $10 \mathrm{~m}$ 以上ある地盤は液状化しやすいことが わかる. 図一-9によると, 河川・水涯線・水面, 旧河道, 緩扇状地は $P_{L}$ 值が大きく液状化しやすく, 三角州, 旧 水面上の高い盛土地・埋土地, 頻水地形で $P_{L}$ 值はやや 高い值を示し, 干拓地, 砂 (礫) 州・砂 (礫) 堆, 高い 盛土地, 谷底平野と凹地・浅い谷では $P_{L}$ 值は小さく液 状化しにくくなっている.

情報相互の関係としては, たとえば図一7では頻水地 形, 干拓地, 旧水面上の盛土地・埋土地の凡例で激しい 液状化現象が発生した割合が大きくなっているが，この 凡例に含まれる $P_{L}$ 值の集計からは，図一9に示すよう に干拓地の $P_{L}$ 值は他の凡例の $P_{L}$ 值より小さな值を示 し，相互関係が整合しない場合もある ${ }^{1)}$.このように， 地形・地質の区分と関東地震の液状化発生・非発生およ び $P_{L}$ 值との関係は，それぞれの情報間に“あいまい” な部分がかなり含まれており，単一の情報だけで予測を 行うことは避けなければならないことがわかる.

他の地形・地質の情報についても同様な検討を行い， 液状化の判定に有為な情報を与える地図情報を選び出し 液状化の可能性と地図情報の関係を求め表一1 に示す.

\section{4. 液状化予測}

\section{（1）メッシュ判定法による液状化予測のフロー}

メッシュ判定法は, メッシュ内の諸情報を重稀わせ て地盤の液状化に対する性質を総合化したうえで液状化 の可能性を表わす方法であり，判定法のフローを図-10 に示す.

ボーリング地点の解析値の統計量（図一3の $P_{L}$ 値亡 統計量）から液状化の可能性のランク值 $「 1$ : 可能性き
表一1 判定に用いる地図情報の分類

\begin{tabular}{|c|c|}
\hline ランク値 & 地図情報 の 分 類 \\
\hline $\begin{array}{l}\text { 液状化の } \\
\text { 可能性大 } \\
\text { ランク值 } \\
2\end{array}$ & 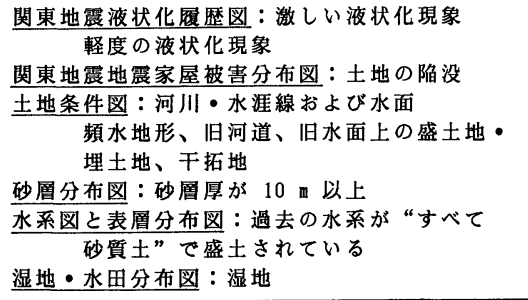 \\
\hline $\begin{array}{l}\text { 液状化の } \\
\text { 可能性いく } \\
\text { らかあり } \\
\text { ランク値 } \\
\quad 3\end{array}$ & 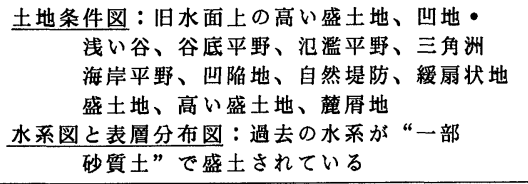 \\
\hline $\begin{array}{l}\text { 液状化の } \\
\text { 可能性なし } \\
\text { ランク值 } \\
4\end{array}$ & 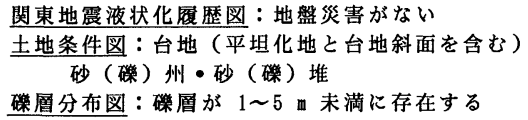 \\
\hline
\end{tabular}

わめて大, 2 : 可能性大, $3:$ 可能性ややあり, $4:$ 可能 性なし，5：判定できず」を決定する．今回の予測では 可能性きわめて大のランク值 1 については解析值に “あ いまいさ”が残されていることを配慮し， ランク值 2 に ランク值 1 を含め, ランク值 $2 \sim 4$ の表示で 3 段階で液 状化の可能性を表わした。地点数とその分布形状から情 報の信頼性を確度 $\Gamma \mathrm{A}$ ：大, $\mathrm{B}$ ：やや大, $\mathrm{C}$ : 中, D : やや小, $E$ :小」として表わした.

液状化の判定に有意な情報を与える地図情報を選定し (表一1), 各地図情報ごとにその情報の凡例がメッシュ 内に占める面積比から液状化の可能性の「ランク值」と 「確度」を決定した. 各地図情報はそれぞれ“あいまい さ”を含みながらも, 液状化の可能性の有無を示す情報 が同一ランク值として多数重なり合えば, 判定值の“確

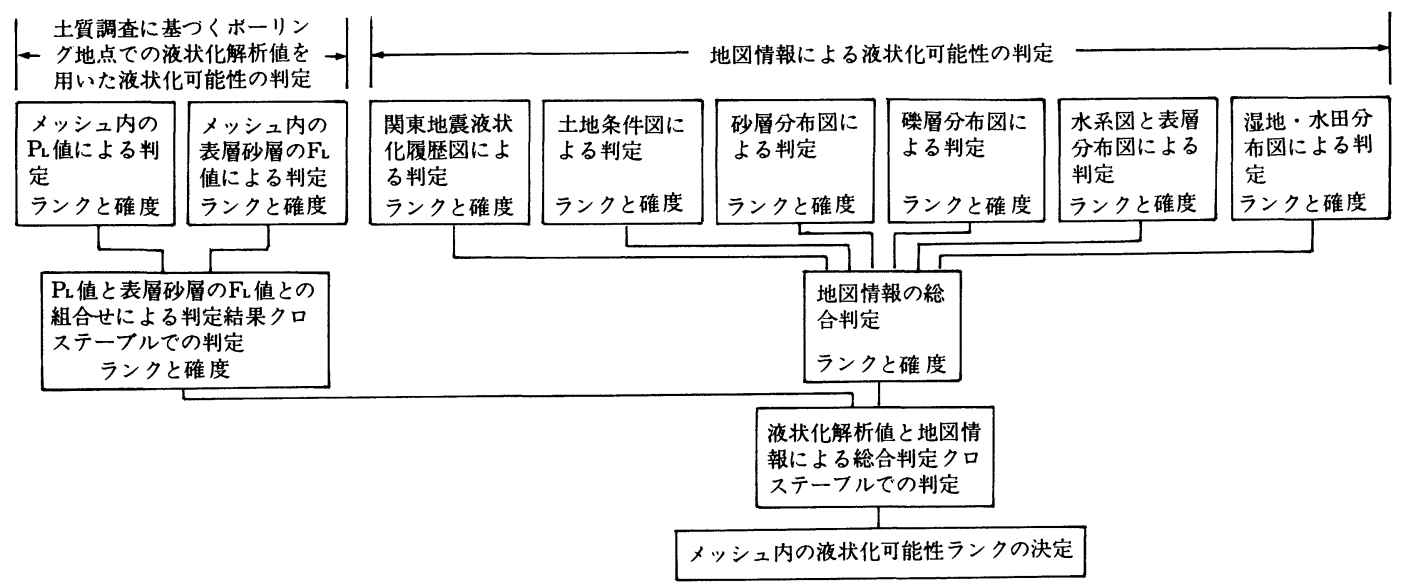

図一10 メッシュ判定のフロー 
からしさ”は増すことになる．このような“並列化”12) した組合せによって各地図情報を統合し, 地図情報全体 を総合化した「ランク值」と「確度」を決定した。

ボーリング地点の解析值による「ランク值」と「確度」 と, 地図情報全体の「ランク值」と「確度」を総合化し てメッシュごとの液状化の可能性を決定した.

\section{（2） ボーリング地点の液状化解析による判定}

砂層の粒度試験デー夕の有無により類似した地盤に対 し液状化の判定結果に大きな差が生じることを避ける目 的で，液状化強度推定式では対象土層に対し粒度による 制限を加えていない ${ }^{3)}$. このため， $P_{L}$ 值による判定は砂 質土層に限定せずに, 粘性土層も含めた地表面下 $20 \mathrm{~m}$ の地盤の強度低下の程度を表わす指標とみなした。図一 6 によると，ここで使用した予测式による $P_{L}$ 值の判定 結果は，岩崎・龍岡ら $\left.{ }^{13}\right)$ が提案した液状化の被害程度と $P_{L}$ 值の関係を採用できることが確かめられ，ここでは， $P_{L}$ 值による液状化判定のランク值を, $P_{L} \geqq 15$ を液状 化の可能性大 (ランク值 2 ), $15>P_{L} \geqq 5$ を可能性いく らかあり(ランク值 3), $5>P_{L}$ を可能性なし(ランク值 4) とした。なお，メッシュ内にボーリング地点がない場合 はランク值 5 に設定した.

また，噴砂・噴水，家屋やライフラインなよ゙の被害は 浅い砂層の液状化の影響を受けやすいことから， $P_{L}$ 值 の判定法以外に, 表層 $6 \mathrm{~m}$ 以浅の砂層厚と $F_{L}$ 值に注目 した “表層砂層の $F_{L}$ 值による判定法”3) を作成した。

地域被害想定のような広域的な液状化予測では，液状 化によって引き起こされる被害の多様性を配慮する必要 がある。ここでは，単一な予測法をとらず，異なる考え に基づく 2 種類の判定値 “ $P_{L}$ 値による判定但”之“表 層砂層の $F_{L}$ 值による判定值”を表一2により統合し, ボーリング地点における液状化の可能性のランク值を決 めた。

メッシュ内のボーリング地点数とその分布状況から解 析結果の信頼性を表わす $\mathrm{A} \sim \mathrm{E}$ の確度を以下のように 定義した．地点数が 15 以上と多くかつ分布が良い場合

表一2 ボーリング地点の液状化判定クロステーブル

$\mathrm{P}_{\mathrm{L}}$ 值による判定

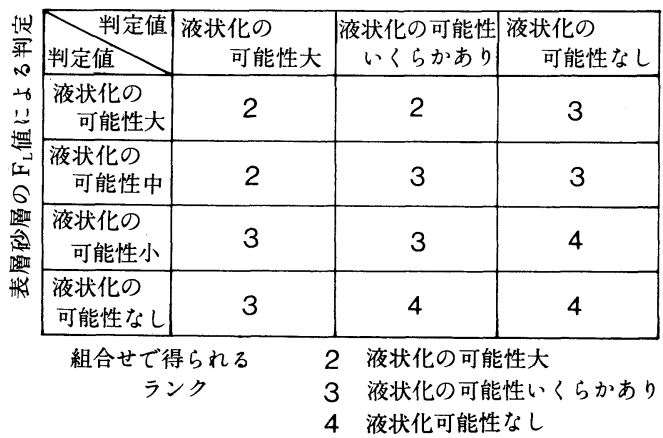

を $\mathrm{A}$ ，地点数が $10 \sim 15$ とやや多くかつ分布が良い場合 を $\mathrm{B}$ ，地点数が 5 - 10 とやや少ないが分布が良いか, あるいは地点数が 15 以上と多いが片寄って分布してい る場合を $\mathrm{C}$, 地点数が $2 \sim 5$ と少ないが分布が良いか, あるいは地点数が 5 - 15 あるが片寄って分布している場 合を $\mathrm{D}$ ，地点数 0 か，あるいは 4 以下と少なくしかも

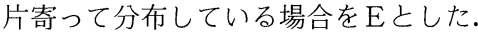

\section{（3）地図情報の解析による判定}

地図情報による判定では，液状化判定に有意な情報を 与えるものとして図一10 のフローに示す 6 種類の分類 に地図情報を整理して，表一 1 に示す分類がメッシュ内 に存在するか否かによって液状化可能性のランク值を決 定した．表一1 に示す分類の大部分は図一1の関係を使 用して東京低地を対象にした解析結果から求められてい るが，“水系図と表層分布図”による判定は，過去に水 系であったところが砂質土で埋土されていれば液状化し やすいという液状化被害で一般的に確認されていること を表わしたものも含まれている.

地図情報の判定の例として土地条件図による判定のフ ローを図一11に示す．判定は液状化可能性なし（ラン ク值 4）の凡例である台地と砂（磇）州・砂（碩）堆を 先に行い，その後で液状化可能性大（ランク值 2) であ る水面・水涯線 - 頻水地形, 旧河道, 干拓地，旧水面上 の盛土地・埋土地を対象として判定した. 最後に液状化 可能性なし，あるいは大と判定できなかった分類を可能 性いくらかあり（ランク值 3）と判定した。メッシュ内

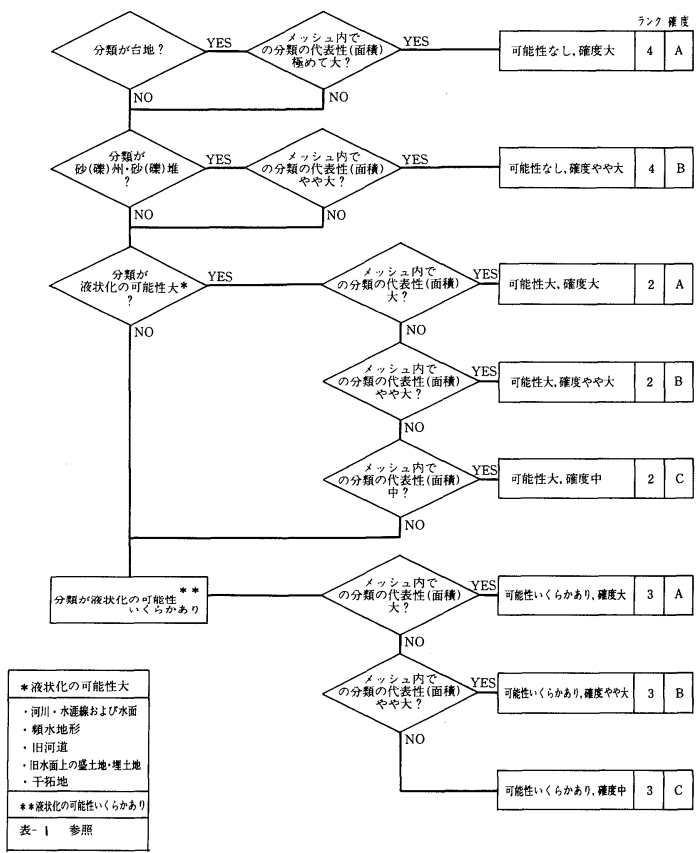

図一11 土地条件図による判定のフロー 


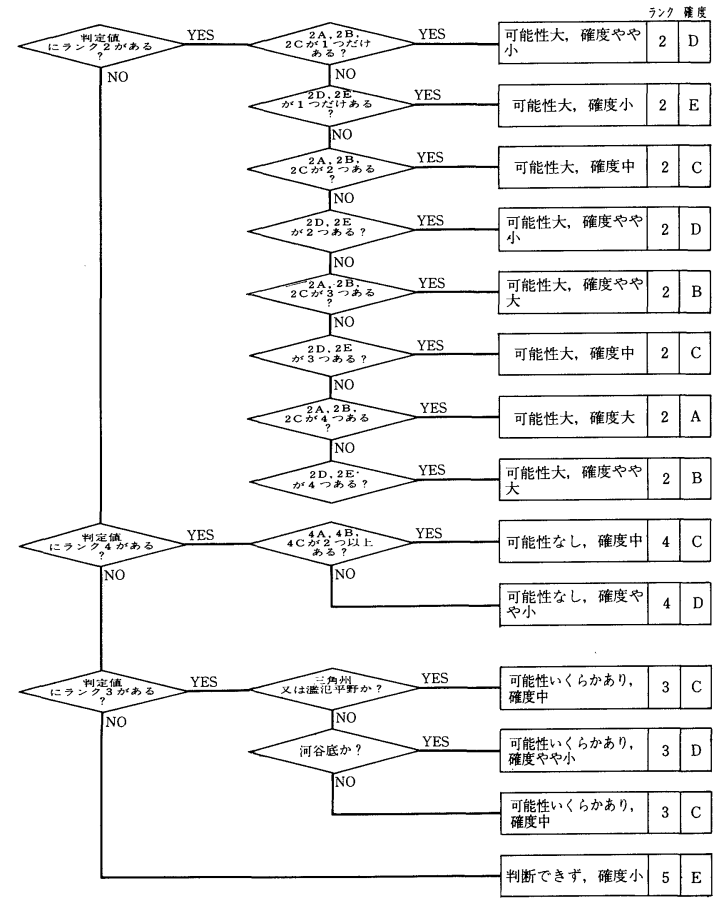

図一12 地図情報による総合判定のフロー

に占める凡例の面積比から確度を $\mathrm{A} \sim \mathrm{C}$ の 3 区分で表 わした。

関東地震液状化履歴図による判定では，履歴図で激し い液状化と軽度の液状化の凡例，および関東地震家屋被 害分布図の土地の陷没した凡例をランク值 2 とし, 履歴 図で被害なしの凡例をランク值 4 とした. メッシュ内に ランク值 2 の凡例が含まれる場合はランク值 2 と判定 し, メッシュ内に占める凡例の面積比から確度 $\mathrm{A} \sim \mathrm{E}$ を決めた.メッシュ内にランク值 2 がなくランク值 4 の 凡例があればランク值 4 と判定した.

砂層分布図では層厚 $10 \mathrm{~m}$ 以上をランク值 2 とし，砂 層分布図では $5 \mathrm{~m}$ 以浅に碩層があればランク值 4 とし て,メッシュ内のその凡例の有無により液状化可能性 大・なしのランク值を決め, その面積比の大小から確度 を決めた。

地図情報の種類によって，各情報のもつ意味合いを配 慮しランク值と確度の決め方に差をもたせた。

6 種類の地図情報における個々の液状化可能性のラン ク值と確度を，図一12のフローにより集約し，総合的 な地図情報の液状化可能性のランク值と確度を決定し た.その手順は，まずメッシュ内にランク值 2 があれば 液状化可能性大と判定し， ランク値 2 の個数と確度から 総合的な地図情報の確度を決定した。 ランク值 2 がなけ ればメッシュの液状化の可能性をランク值 4 の有無で判 断し, ランク值 4 があれば液状化の可能性なしと判定し,
ボーリング地点での液状化解析值を用いた液状化可能性の判定

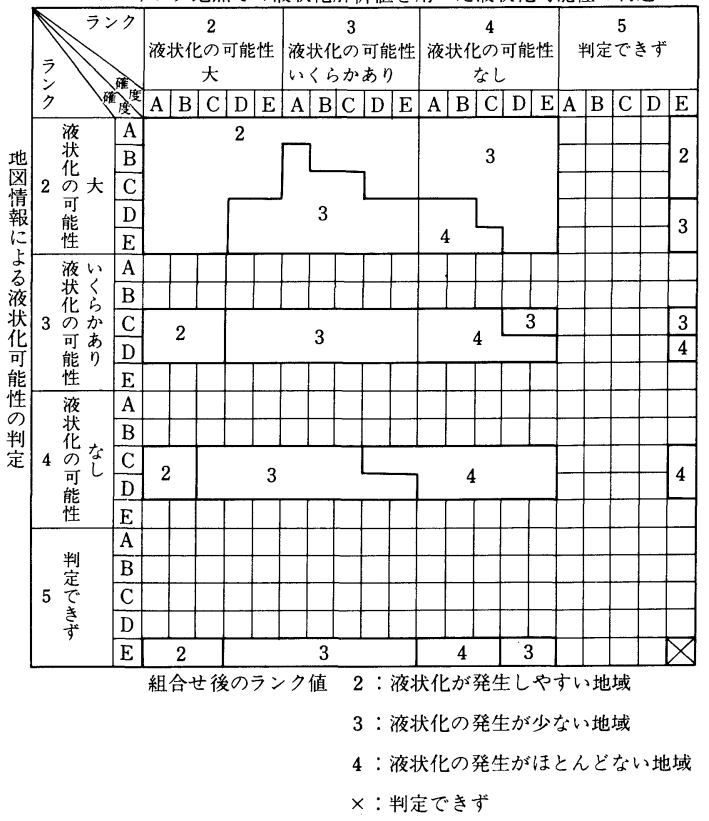

図一13 液状化解析值と地図情報による総合判定フロー

ランク值 4 の個数により確度を決定した. 以上 $2 つ$ の判 定加外れるものは液状化可能性大とも可能性なしとも 判断できないことから，中間的な判定值として液状化可 能性いくらかありと判定した。

\section{（4）総合評価に基づく液状化予測}

横軸にボーリング地点, 縦軸に地図情報の液状化可能 性のランク值と確度を設定し, 図一13 に示すクロステー ブルにより，その組合せから総合判定值を決定した。図 一13による総合判定では，ボーリング地点と地図情報 の液状化可能性のランク值が等しい場合はそのランク值 を総合判定值とした．両者のランク值に差がある場合は 確度の高いランク值を総合判定值とした。ただし, 両者 のランク值が同じであっても確度が低い場合は，中間の ランク值 3(液状化可能性いくらかあり)にした。このク ロステーブルはボーリング地点の解析結果のランク值を 地図情報のランク值より若干優先させ, 判定の確度がそ しい組合せはランク值 3 になるように設定されている.

ボーリング地点と地図情報の個々の判定までは，ディ スプレイの出力図から判断した. 個々の判定結果をパソ コンに入力し，図一13 のクロステーブルを使用し対象 地域全域のメッシュのランク值を決定した.

以上のような予測過程をふまえて作成したメッシュ判 定法による液状化予測図を図一14に示す。この図によ ると, 湾岸部の最近埋立てた地域を除くと, 液状化が発 生しやすい地域は東京低地の約 4 分の 1 である. 


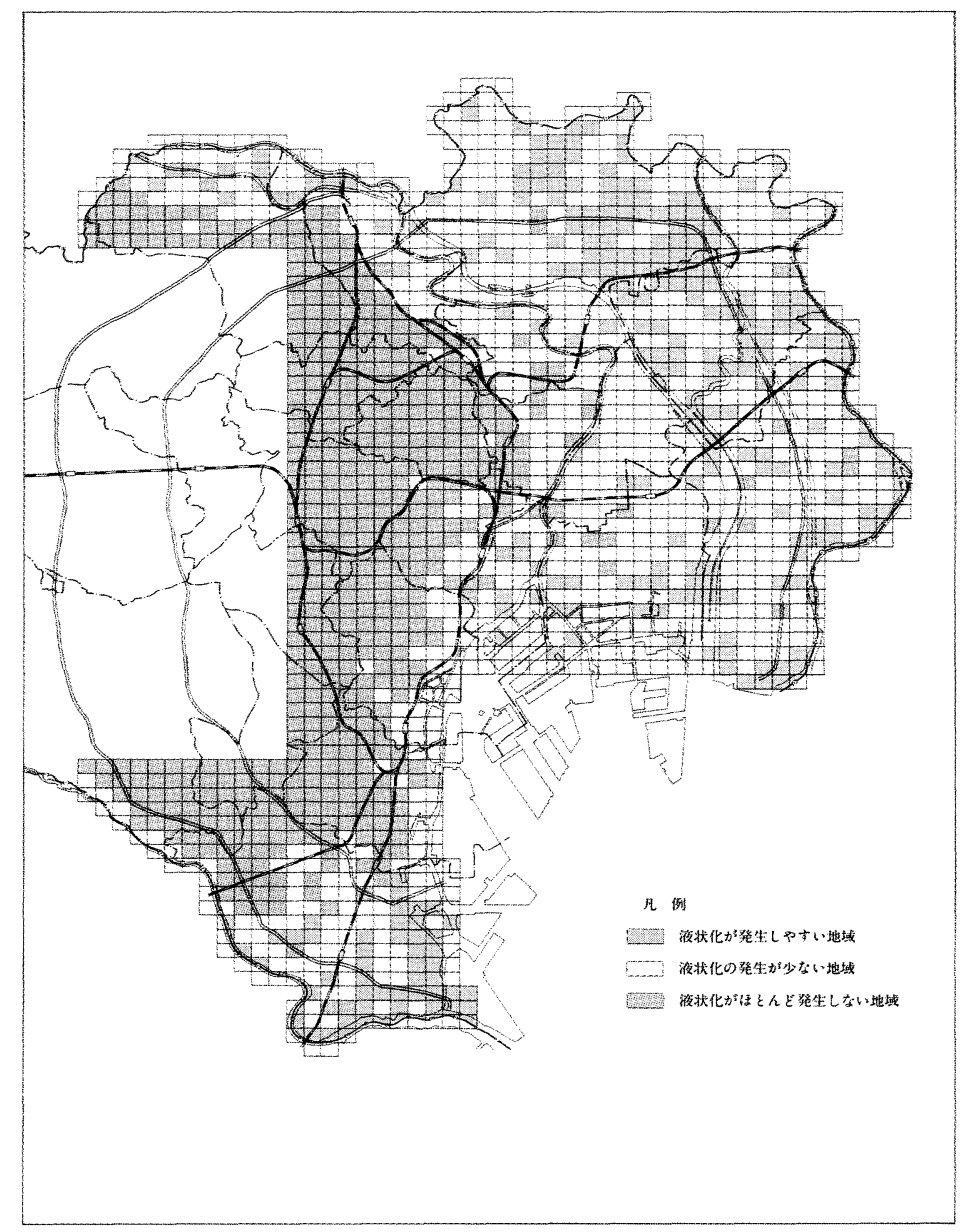

図一14 メッシュ判定による東京低地の液状化予測図

\section{5.おわりに}

今回の液状化予測のように個々の情報と解（予測値） との間の因果性が比較的乏しい問題では，情報個別の分 析的な解析よりむしろ情報相互の関係からどのようにし て総合化に向かうかのプロセスの構筑が重要であり, 予 測精度の向上とともに予測に至る過程の合理性も重要な 課題になる。ここでは，予測法とともに，この種の問題 でブラックボックスにしがちな予測過程のプロセスにつ いても説明を加えた.

\section{参 考 文 献}

1）東京都土木技術研究所：東京低地の液状化予測, 土質工 学会, 1987.

2) 草野 郁: 関東地震における東京低地の液状化履歴, 土 木学会論文集, No. 406/III-11, pp.213～222, 1989.

3) 草野 郁：細粒分を含む砂質地盤の液状化強度の推定法, 土木学会論文集, No. 418/III-13, pp. 55 64, 1990.
4）高速道路調査会・橋梁構造研究会：耐震設計に関する調 查研究, 日本道路公団, pp. 57 62, 1979.

5）建設省国土地理院: 土地条件図, 東京東北部, 東京東南部, 東京西北部, 東京西南部, 1970.

6）農商務省地質調査所：関東地震調査報告, 1925 .

7）建設省国土地理院：1：25000 洪水地形分類図, 東京周辺 の水害危険地帯, 1961 .

8）第一軍管地方迅速測図：参謀本部陸軍部測量局, 大日本 測量 (株)，資料調査部複製.

9）正井泰夫：都市環境としての大江戸の水系と海岸, 人文 地理学研究IV, 筑波大学地球科学系, 1980 .

10）東京都土木技術研究所: 東京都地盤地質図 (23 区内), 1969.

11）建設省国土地理院地図管理部：国土数値情報の概要, 1983.

12）寺野寿郎：システム工学入門, 共立出版, 1986.

13）岩崎敏男・龍岡文夫・常田賢一・安田 進 : 砂質地盤の 地震時流動化の簡易判定法之適用例, 第 5 回日本地震工 学シンポジウム講演集, pp. 641〜 648, 1978.

(1989.5.24 • 受付) 